\title{
Reply to Pietro Bortone
}

\author{
Silvia Luraghi \\ Università di Pavia \\ silvia.luraghi@unipv.it
}

I find Pietro Bortone's acrimonious reaction amusing and his accusation of plagiarism simply ridiculous (allegedly, I copied the substance of my 363-page book on primary prepositions in Homer and Attic-Ionic from his book, which devotes a chapter of 63 pages to Homeric and Classical Greek, including various authors that were not in my corpus and several non-primary prepositions). Regarding our meeting in Paris two weeks after 9-11-2001, I have rather different recollections. I doubt having ever said that I dreamed of writing a book such as his: most likely, I said I was writing a book on Greek prepositions in Homeric and Classical Greek, which was indeed what I was doing at that moment (my 2003 book was submitted in the spring of 2002). I did express interest in his work as I am obviously interested in anybody else's work related to mine; however, even though over three decades colleagues may have discovered errors in some of my publications, nobody has ever detected any plagiarism. The atmosphere was friendly and collaborative, as shown by Bortone's answer to my inquiry about the book he had promised to send me. He wrote (3-18-2002): "I'm greatly embarrassed. After your email I made a phone call and discovered that my parents whom I had asked to send you the thesis haven't done that .... You shouldn't have been so kind as not to say anything for months!"

In my 2005 paper on metá that he says he peer-reviewed I did refer to his book, and not marginally: I mentioned his description of the semantic evolution exactly where I spoke of such evolution (e.g.: "As argued in Bortone (2000: 222), after the phonological reduction of metá = 'with' to me, there was space for another metá = 'after', since there was now a formal distinction between the two meanings."). However, my central claim, i.e. that the formal split pointed to the existence of two homophones already in Classical Greek, is nowhere to be found in Bortone's book. To say that I duplicated his material sounds imaginative, considering that I did my own corpus study of Byzantine and Middle Greek (which should reassure readers regarding my knowledge of Medieval Greek) and none of my examples are to be found in his book (Modern Greek examples 
were, as acknowledged, the courtesy of a colleague, who had also received Bortone's thesis after the Paris conference and, as many others, failed to discover plagiarism). The section on Homeric and Classical Greek did not draw on Bortone's book, especially because his treatment of metá has serious flaws. On p. 159 (= Bortone 2000:181), he shows that metá+dative and metá+genitive could occur in similar contexts (omitting that metá+accusative could occur in similar contexts too) and concludes that "the dative was the weaker case" so it was eliminated. But he fails to show in what sense it was the weaker case, considering that the ratio of dative:genitive in Homer is 215:5 (Hagget 1902); I base my analysis on a wider consideration of usages with all three cases and in-depth semantic analysis, which I certainly couldn't have taken from his book because it's not there. (Remarkably, in a three-line addition to the 2000 version, Bortone manages to slip in a real mistake regarding metá. In Bortone 2010:167 he states that "the genitive appears in Homer with plurals and collective singulars." This is simply false: the five occurrences with the genitive all feature count plurals; cf. Chantraine 1953:119. It is the accusative which, in the meaning 'among', only occurs with collective singulars and plurals modified by pâs 'all'; cf. Chantraine 1953:118.) Interestingly, when the paper was rejected by the journal, the report didn't show much concern with the Greek data, and I was not surprised that the same paper, virtually unchanged, fared much better in a journal mostly devoted to Greek.

Often, Bortone eschews answering. Regarding diá, the point is not whether I did or did not mention Schwyzer, but rather that he (I can only repeat what I've already written) refers to the use of diá+accusative and diá+genitive in the PPs dià núkta 'in the night' and dià nuktós 'during the night' as "indiscriminate use of cases in PPs" (Bortone 2010:159), without considering that the first expression is only Homeric, and that after Homer diá+accusative denotes Cause, while the second is only post-Homeric, and that in Homer diá+genitive never denotes Time. So I am not the one who needs to refer to standard handbooks here, but rather he. Concerning the extension of diá to Beneficiary, again I based my observations on a corpus study (presented in Luraghi 2005; needless to say, none of the examples is to be found in Bortone's book). What I had written to him was that I didn't understand why he, though remarking that diá acquired a Beneficiary meaning (based on a single example from Jannaris 1897, hardly a new discovery, cf. Bortone 2010: 235), failed to consider the Purpose meaning. His answer (3-21-2002) was that, regarding this type of extension, "diá did not fall into the category" of prepositions he considered for the Medieval Greek period, so "I haven't studied it at all."

I, too, find unfortunate that someone failed to realize that the figure in Luraghi (2003:166) was by Bortone, as I made clear that I didn't commit to that interpretation saying that it "cannot be demonstrated based on the literary 
language." (2003:165). If one considers the evidence adduced by Bortone for plagiarism, it all boils down to two short paragraphs in the last section of my book. The first one (four lines) contains the sentence: "Prepositions also develop new abstract meanings." (Luraghi 2003: 331), and continues mentioning the loss of the dative. Does this development, which is virtually universally undergone by adpositions in any language need a reference (especially considering that most of the $33^{\circ}$ preceding pages are about semantic extension of prepositions)? On p. 332 I wrote:

Already in the time stretch analyzed in this book [based on numerous examples I dug out
of my corpus], prepositions acquire an increasingly abstract meaning. Concrete meanings
expressed by this set of prepositions in Homer are often expressed by newly created adverbs
and adverbial prepositions in Classical Greek: the latter are mostly reinforced forms of the
prepositions such as kátō, 'below', and áno, 'on', substituting katá and aná, which had lost
(most) local reference [something that is common knowledge for anyone acquainted with
Greek]. In later Greek this process continued, and led to the disappearance of a number of
the prepositions reviewed in this book, while others remained limited to the expression of
highly abstract meanings or of grammatical relations.

Considering that part of the paragraph summarizes things that I had discussed, did I really need to read Bortone's book to know that many Ancient Greek prepositions are no longer there in Modern Greek and that new ones have emerged? Most notably, does Bortone really think that this is a summary of his book? This would mean he has a poor opinion of his own work.

My review was not all about the fact that he didn't quote my book, but rather that, except for Hewson and Bubenik (2006) (only quoted in the first chapter in the general discussion, not in the chapters on Greek prepositions), he mentions no bibliography on Greek cases and prepositions published from 2000 onward. (Remarkably, reference to my 2003 book is to be found in other reviews, including those by Pappas in Diachronica and by George in LinguistList, who calls it 'an admirable introduction to the cases and prepositions of the ancient language' apparently failing to realize that I supposedly copied everything from Bortone, and not only by 'innocent' Bubenik, whom I allegedly misled.) Bortone points out that my book contains seven pages of references while his contains over thirty-one: this makes it even more remarkable that he did not find a single study on Greek prepositions worth mentioning among those which were published after he finished his thesis, especially because pre-200o bibliography is quoted in great detail. Should this be taken to imply he has the feeling that since 2000 everybody else has just been copying from his book? If one goes through the text as I have done, one has the feeling that for some reason Bortone had to delay publication of a book which was virtually finished in 2000. In the years in-between, he added some paragraphs to the first chapter, partly based on additional bibliography, but seems not to have made significant changes to the 
remainder of the book, which often follows the first version word by word; sometimes even typo by typo, as in the case of Horrocks' first name initial, which is once G. and once J. (Bortone 2010:317 and 2000:381). One shouldn't be misled by the table of contents: seemingly added sections mostly result from fragmentation of the already existing text.

Finally, Bortone points out that I "turned her [= my] own thesis into a small book after fifteen years," perhaps implying that he did much better. While I find his remark irrelevant, let me point out that he refers to my MA thesis, which, as I said in the introduction of that book, marked the origin of my interest for Greek prepositions, but that the book, though small, was a new book, and by no means a copy of a thesis already available as a pre-print like his. In the years between my MA (1982) and the publication of the 1996 book, I was active with other work, publishing around thirty scholarly articles, some of which are extensively quoted, doing my $\mathrm{PhD}$, writing my $\mathrm{PhD}$ thesis on a completely different topic, defending it in 1987 , and publishing a book featuring a completely rewritten and enlarged version of the first two chapters on the thesis, based on a much wider corpus (Luraghi 1990, cf. p. vii).

\section{References}

Bortone, Pietro. 200o. Aspects of the history of Greek prepositions - a localistic view. Oxford DPhil.

Bortone, Pietro. 2010. Greek prepositions - from antiquity to the present. Oxford: Oxford University Press.

Bortone, Pietro. 2012. Response to the Review by Silvia Luraghi of Greek Prepositions: From Antiquity to the Present. Journal of Greek Linguistics 12(1): 189-197.

Chantraine, Pierre. 1953. Grammaire homérique. Tome 2: Syntaxe. Paris: Klincksieck.

Haggett, A.S. 1902. On the uses of the prepositions in Homer. Studia Gildersleeve, 181-187.

Hewson, John, and Vit Bubenik. 2006. From case to adposition - the development of configurational syntax in Indo-European languages. Amsterdam: Benjamins.

Luraghi, Silvia. 1990. Old Hittite Sentence Structure. London/New York: Routledge.

Luraghi, Silvia. 2003. On the meaning of prepositions and cases: the expression of semantic roles in Ancient Greek. Amsterdam: Benjamins.

Luraghi, Silvia. 2005. Paths of Semantic Extension-From Cause to Beneficiary and Purpose. In M. Fortescue, E. Skafte Jensen, J.E. Mogensen, \& L. Schøsler, Historical Linguistics 2003. Amsterdam/Philadelphia: Benjamins, 141-157. 


\title{
Presenting the "Brill" Typeface
}

\author{
brill.nl/brill-typeface
}

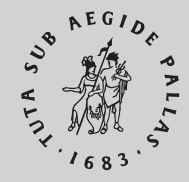

B R I L L

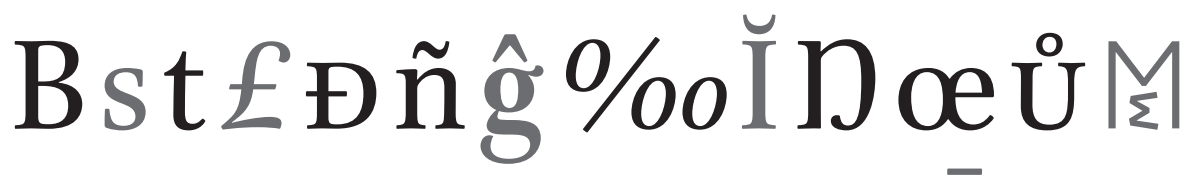 hv::rqă $q \bar{Æ} \bar{\emptyset} \mathbf{U} 8 \bar{B} \mathrm{~Bq}$ $\forall{ }^{\circ} \mathrm{z} \vee \gamma_{1} \odot . . И \ni \Delta \boxplus \Psi$ $\theta \bullet \ni \rho Д \breve{\mathbf{y}} \mathbf{i} Э л \xi \boldsymbol{\phi} \mathfrak{R}$ s $ち$ Væ⿱ th $\mathrm{pH}$ m $f f t t$}

After careful consideration, Brill has taken the initiative of designing a typeface. Named "the Brill", it presents complete coverage of the Latin script with the full range of diacritics and linguistics (IPA) characters used to display any language from any period correctly, and Greek and Cyrillic are also covered. There are over 5,100 characters in all. This indispensable tool for scholars has become freely available for non-commercial use. You can download the font package after agreeing to the End User License Agreement. "The Brill” is available in roman, italic, bold, and bold italic, with all necessary punctuation marks and a wide assortment of symbols. It will be especially welcomed by humanities scholars quoting from texts in any language, ancient or modern. "The Brill" complies with all international standards, including Unicode. John Hudson of Tiro Typeworks, well-known for his multilingual fonts, is the Brill's designer.

You can download the font on our website brill.nl/brill-typeface 